\title{
Pituitary Atypical Adenoma or Carcinoma Sensitive to Temozolomide Combined with Radiation Therapy: A Case Report of Early Identification and Management
}

\author{
Radyoterapiyle Kombine Edilen Temozolomid Duyarl Pituiter Atipik \\ Adenom veya Karsinom: Erken Tanımlama ve Yönetimle İlgili Bir Olgu
}

\section{Sunumu}

Chuanhong ZHONG ${ }^{1}$, Senlin YIN², Peizhi ZHOU², Shu JIANG²

${ }^{1}$ The Affiliated Hospital of Luzhou Medical College, Department of Neurosurgery, Sichuan Province, PR China

${ }^{2}$ Sichuan University, West China Hospital, Department of Neurosurgery, Chengdu, Sichuan Province, PR China

Corresponding Author: Shu JIANG / E-mail: jiangshu2000@126.com

\begin{abstract}
Pituitary carcinoma is extremely rare and difficult to diagnose early. Here we present a case of highly suspected pituitary malignant adenoma with early chemotherapy and radiation. A 30-year-old woman was admitted for headache and impaired vision, MRI found a sellar mass. Since there was no disturbance in serum hormone levels, she was diagnosed with non-functioning pituitary adenoma before surgery. Transsphenoidal removal of tumor was attempted but only partial resection of tumor was achieved. Pathology findings suggested a diagnosis of adenocarcinoma. PET-CT scan showed the tumor had elevated max standardized uptake value. No other abnormal sites were found, which excluded metastasis to pituitary. After surgery, the patient was treated with temozolomide assisted with radiation and tumor disappeared on MRI. No recurrence was observed on 1-year follow up. In conclusion, early temozolomide with radiation therapy for highly suspected pituitary carcinoma might be beneficial.
\end{abstract}

KEYWORDS: Pituitary atypical adenoma, Pituitary carcinoma, Diagnosis, Temozolomide

öz

Pitüiter karsinom çok nadirdir ve erken tanı konulması zordur. Burada pitüiter malign adenomdan yüksek ölçüde şüphelenilen bir olguda erken kemo ve radyoterapi uygulanışını sunuyoruz. 30 yaşında bir kadın başağrısı ve bulanık görme ile geldi ve MRG'de sella kitlesi bulundu. Serum hormon seviyelerinde bir bozukluk bulunmadığından ameliyattan önce işlevsel olmayan pitüiter adenom tanısı kondu. Tümörün transsfenoidal yolla çıkarılması denendi ancak sadece kısmi rezeksiyonu yapılabildi. Patoloji bulguları adenokarsinom tanısı düşündürdü. PETBT taraması tümörün maksimum standardize kontrast tutma değerinin artmış olduğunu gösterdi. Başka bir anormal bölge bulunmadı ve bu durum pitüitere metastaz olasılığını ortadan kaldırdı. Cerrahiden sonra hasta temozolomid ile birlikte radyoterapi ile tedavi edildi ve MRG'de tümör kayboldu. Bir yıllık takipte nüks gözlenmedi. Sonuç olarak yüksek ölçüde şüphelenilen pitüiter karsinom için erken temozolomid ile radyoterapi faydalı olabilir.

ANAHTAR SÖZCÜKLER: Pitüiter atipik adenom, Pitüiter karsinom, Tanı, Temozolomid

\section{INTRODUCTION}

Pituitary adenomas account for about $15 \%$ of intracranial tumors, however, pituitary carcinoma is a very rare condition, accounting for about $0.1 \%$ of pituitary tumors (6). The diagnosis of pituitary carcinomas usually depends on the spread of central nervous system or remote metastasis. Once diagnosed, the prognosis of this disease is very poor despite surgery, radiation and chemotherapy (7). Before metastasis is confirmed, these patients were usually diagnosed as atypical or aggressive pituitary adenomas and repeated surgeries are usually performed (2). Here we reported a case of highly suspect pituitary carcinoma without metastasis, which was sensitive to early radiochemotherapy after surgery. We proposed that early radiochemotherapy might be beneficial for these highly suspect patients, in spite of no confirmed metastasis.

\section{CASE REPORT}

A 30-year-old woman was admitted for headache and impaired vision for 20 days. She denied polyuria, menolipsis and change of appearance. Neurologic examination showed impaired vision and visual field. MRI suggested a pituitary macroadenoma with invasion of left cavernous sinus (Figure 
1A). Laboratory examination was accordant to pituitary non-function adenoma with decreased thyroid hormones. The patient was diagnosed with non-functional pituitary adenoma and underwent transsphenoidal tumorectomy. During operation, the tumor was found to be relatively hard and bled easily even under light touch. Intraoperative frozen section suggested malignancy. Only partial resection of tumor was achieved. 3 days after operation, enhanced MRI showed a large residual tumor (Figure 1B).

Pathological findings suggested possibility of malignancy. $\mathrm{H}-\mathrm{E}$ staining showed moderate heteromorphism, frequent mitosis, extensive invasion into adjacent normal pituitary tissue and blood vessels (Figure 2A-C). Immunohistochemistry showed that tumor cells were positive for cytokeratin (CK) 8, 18, 19, and protein kinase $C(P K C)$, negative for $C K-5,6$, 7. Staining of markers for hematological system tumors such as cluster of differentiation (CD) 30, CD45 and CD117 were negative for tumor cells. Carcinoembryonic antigen (CEA) and alphafetoprotein (AFP) were also negative. PRL staining was weakly positive, same as synaptophysin. The proliferative index Kiel University (Ki) 67 was about 20\% positive (Figure 2D). In order to exclude metastatic tumor, positron emission tomography/ computed tomography (PET-CT) was ordered. No other foci were found by PET-CT except an abnormal concentration at left sellar area. The max standardized uptake value (SUVmax) of ${ }^{18} \mathrm{~F}$-fluorodeoxyglucose $\left({ }^{18} \mathrm{~F}-\mathrm{FDG}\right)$ was 6.73 .

Postoperative concurrent radiochemotherapy with temozolomide was started 1 month after surgery. Conventional external beam radiothrapy was given for 7 weeks, and concurrent temozolomide was given at dose of $200 \mathrm{mg}$ qd, 5 days per week for 4 consecutive weeks, every two months. At the end of the first treatment cycle, enhanced MRI showed significant shrinkage of tumor (Figure 1C). Another 3 cycles of temozolomide-only therapy performed every 2 months. MRI confirmed complete response and no recurrence for 1 year after surgery (Figure 1D), the patient complained of no discomforts except mild headache. Hormone replacement therapy was offered with T4 25ug/d. Serum hormone levels were normal.

\section{DISCUSSION}

Pituitary carcinoma is an extremely rare condition, which accounts for only $0.1 \%$ of all pituitary tumors (6). Pituitary carcinoma is diagnosed if tumor tissue is not contiguous with pituitary gland or remote metastasis is confirmed. Diagnosis of pituitary carcinoma could not be confirmed until metastasis occurred, which usually takes months or even years after
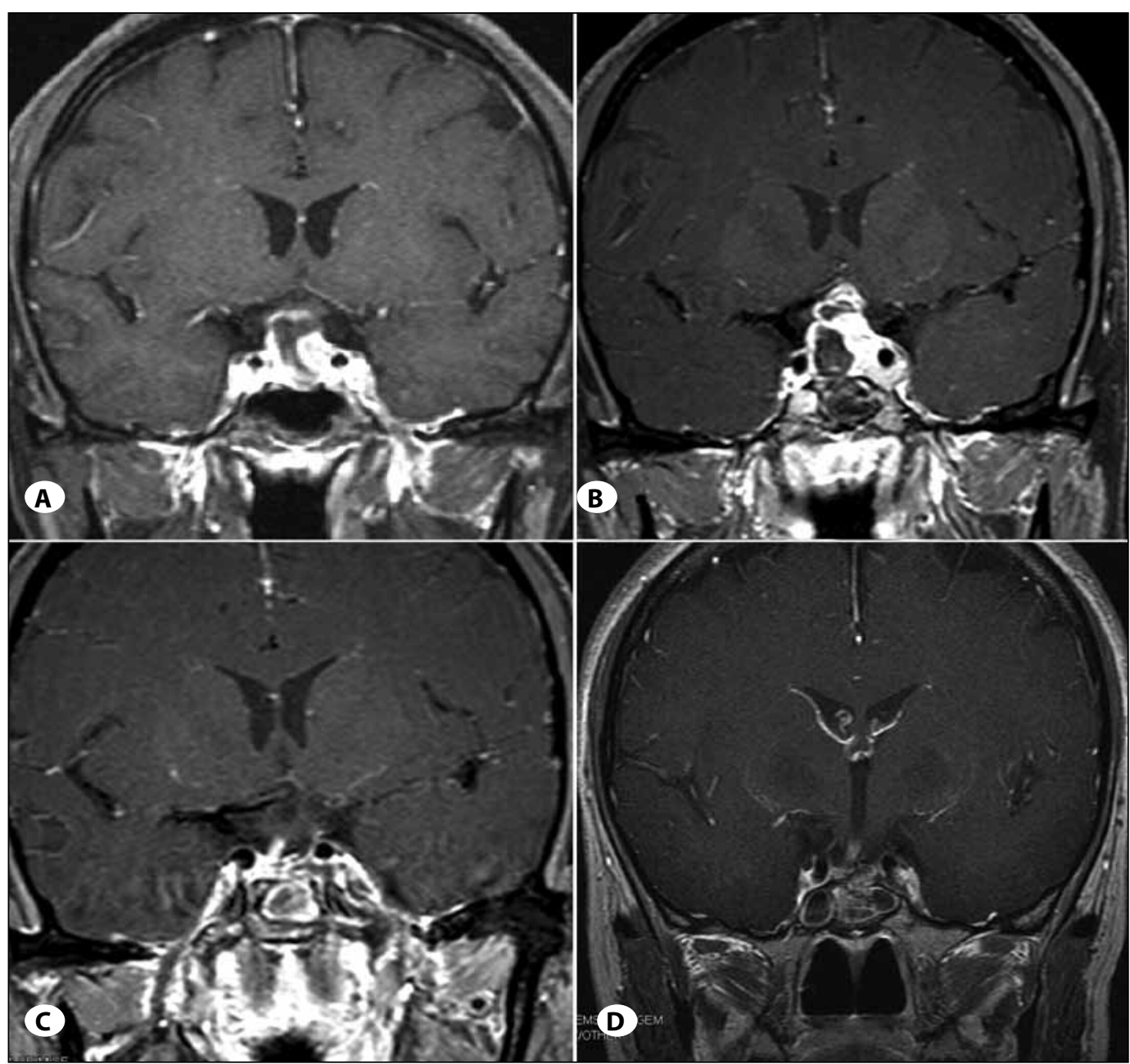

Figure 1: A) Contrast enhanced MRI preoperation showed mass in the left side of pituitary gland. B) MRI 3 days after operation showed the residual tumor. C) MRI 1-month after concurrent radiochemotherapy with temozolomide. D) Complete response in MRI 12 months after surgery. 

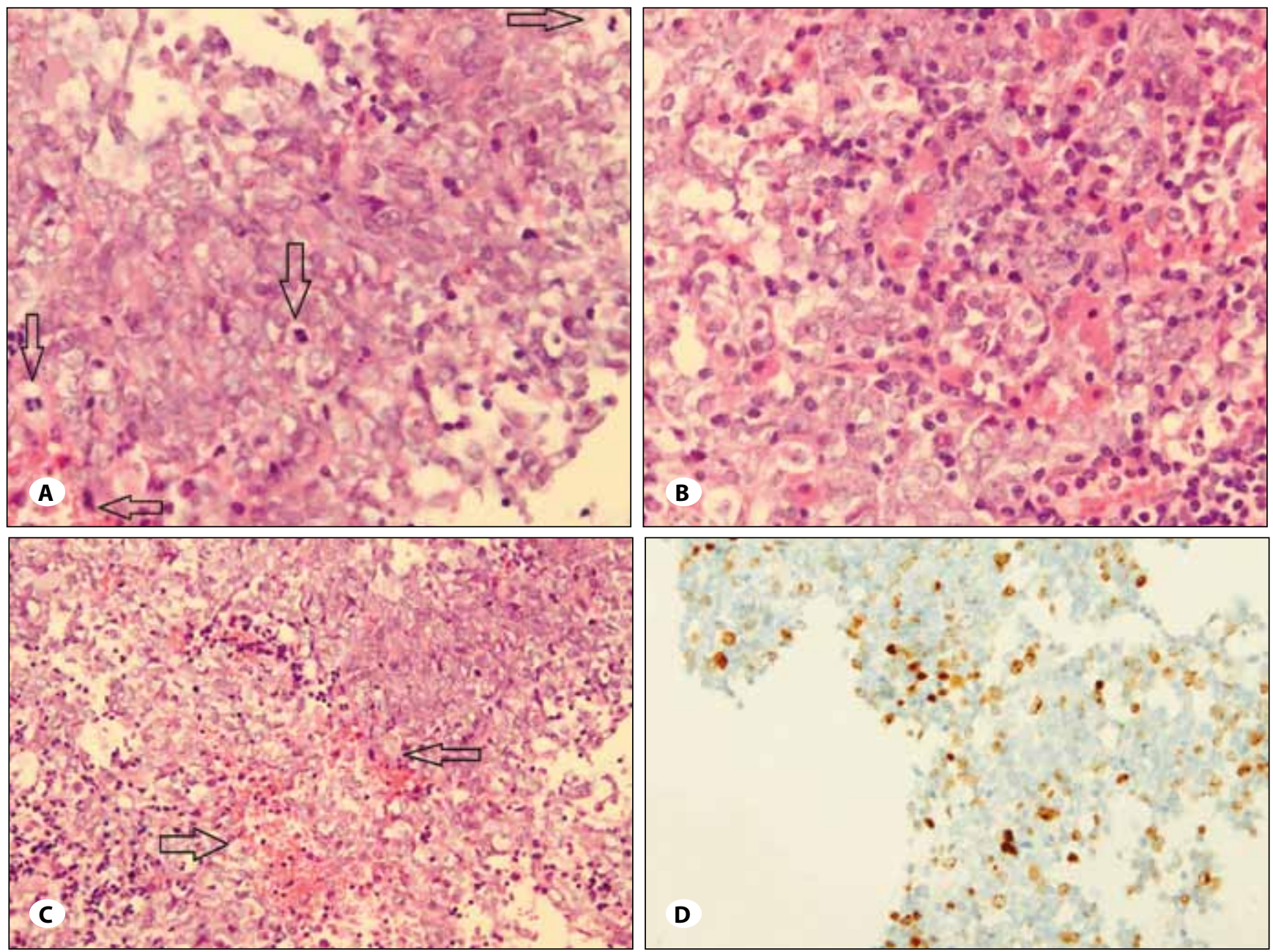

Figure 2: A) Moderate heteromorphism and frequent mitosis(arrows) of tumor cells (H-E, x400). B) Invasion of normal pituitary tissue $(H-E, x 400)$. C) Vascular invasion(H-E, x200). D) Immunohistochemistry showed moderate Ki-67 expression (about 20\%, x200).

initial clinical manifestation. Before metastasis, most patients would be diagnosed with atypical or aggressive tumor. Repeated surgeries are often performed before metastasis is confirmed (2). According to World Health Organization (WHO) classification, pituitary tumors presenting with aggressive biological behavior, elevated mitotic index, Ki67 > 3\% and extensive p53 expression are classified as atypical pituitary tumors. The process "from adenoma to carcinoma" takes months to years, with an average of 89 months (1). During this process, most patients are treated as "benign tumor" until metastasis is found. Once diagnosed, the prognosis is poor. Most patients died within 1 year after final diagnosis $(1,6)$.

We did not find metastasis in this patient to confirm diagnosis of carcinoma. Nevertheless, clues strongly suggested the malignancy of this tumor. During operation, the surgeon with over 15 years experience in operation of pituitary adenomas, found the tumor was distinct from pituitary adenomas. Intraoperative frozen section also suggested malignant tumor. Postoperatively, pathological findings showed moderate heteromorphism, frequent mitosis and invasive behavior (Figure 2A-C), with $\mathrm{Ki}-67$ expression about
$20 \%$ positive (Figure 2D). High Ki-67 expression suggests more aggressive behavior. Dudziak et al. reviewed 132 cases of pituitary carcinoma with 19 reported Ki-69 expression, the average expression was $12 \%$, they suggested Ki-67 level exceeding $10 \%$ should always raise suspicion of malignancy (1). It was reported the mean labeling indices of Ki-67 in pituitary carcinomas was $11.9 \pm 3.4 \%$, while $1.4 \pm 0.15 \%$ in adenomas. However, some reports suggested there is no necessary association between $\mathrm{Ki}-67$ and aggressive behavior (2). $\mathrm{Ki}-67>3 \%$ was recommended by $\mathrm{WHO}$ as one diagnostic criteria for atypical adenoma, but not recommended for pituitary carcinoma (5).

PET-CT was performed to eliminate possible metastasis of this tumor or other primary malignant tumor which may have metastasized to pituitary in this patient. No other abnormal concentration of ${ }^{18} \mathrm{~F}$-FDG was found, and the SUVmax of tumor site was 6.73. Though several studies reported cases with increased FDG uptake in pituitary adenomas, the overall sample size is still small (3). No diagnostic reference is currently available about the SUVmax diagnostic cut-off value for ${ }^{18} \mathrm{~F}-\mathrm{FDG}$ in pituitary carcinomas. 
Therapy for pituitary carcinoma, current treatments consist of reoperation, conventional radiation or radiosurgery and systemic chemotherapy (2). Temozolomide is an alkylating chemotherapy drug initially approved for glioblastoma therapy and was reported in successful management in aggressive pituitary adenoma and pituitary carcinoma in several cases in recent years (8). Kovacs et al. observed histological changes including necrosis, hemorrhagic areas, connective tissue accumulation and focal inflammatory infiltration in an aggressive prolactin pituitary adenoma in response to temolozomide therapy (4).

Considering the pathology results and PET-CT, we diagnosed this patient with atypical pituitary adenoma with highly suspected malignancy. Based on this diagnosis, we offered more aggressive therapy strategy using temozolomide combined with conventional radiation. Zemmoura et al. compared the prognosis of two cases with prolactinoma adopting different therapeutic strategy, suggesting early diagnosis of malignancy before metastasis and aggressive therapy strategy might be beneficial. They suggested that invasive macroprolactinoma resistant to dopamine agonists, with at least 2 of 3 positive cell cycle markers, vascular invasion, abnormal mitoses, Ki-67>10 \%, p53>5\% and allelic loss of chromosome 11, should be considered malignant (9). Dudziak et al suggested frequently relapsing, invasive adenoma with high expression of $\mathrm{Ki}-67$ should raise suspicion of malignancy (1). In our case, though no metastasis was observed, intraoperative and pathological findings (moderate heteromorphism, frequent mitosis, Ki67 about 20\%, invasiveness of normal pituitary and vessels) strongly suggested possibility of malignancy. We chose aggressive therapy strategy using temozolomide combined with conventional radiation, the tumor disappeared after this therapy with no recurrence in 1 year follow-up.

In conclusion, depending solely on metastasis to confirm pituitary carcinoma diagnosis might be sacrificing patient's survival likelihood, since metastasis usually doesn't occur until the very late period of a malignancy, with limited treatment options available. Therefore, we propose early identification and more aggressive therapy for highly suspected malignant pituitary tumor patients, and believe that temozolomide might be a good choice of medicine.

\section{REFERENCES}

1. Dudziak K, Honegger J, Bornemann A, Horger M, Mussig $\mathrm{K}$ : Pituitary carcinoma with malignant growth from first presentation and fulminant clinical course--case report and review of the literature. J Clin Endocrinol Metab 96:26652669, 2011

2. Heaney AP: Clinical review: Pituitary carcinoma: Difficult diagnosis and treatment. J Clin Endocrinol Metab 96: 3649-3660, 2011

3. Jeong SY, Lee SW, Lee HJ, Kang S, Seo JH, Chun KA, Cho IH, Won KS, Zeon SK, Ahn BC, Lee J: Incidental pituitary uptake on whole-body 18F-FDG PET/CT: A multicentre study. Eur J Nucl Med Mol Imaging 37:2334-2343,2010

4. Kovacs K, Horvath E, Syro LV, Uribe H, Penagos LC, Ortiz LD, Fadul CE: Temozolomide therapy in a man with an aggressive prolactin-secreting pituitary neoplasm: Morphological findings. Hum Pathol 38:185-189, 2007

5. Laws ER Jr, Lopes MB: The new WHO classification of pituitary tumors: Highlights and areas of controversy. Acta Neuropathol 111:80-81, 2006

6. Lim S, Shahinian H, Maya M, Yong W, Heaney A:Temozolomide: A novel treatment for pituitary carcinoma. Lancet Oncol 7:518-520,2006

7. Pasquel FJ, Vincentelli C, Brat DJ, Oyesiku NM, loachimescu AG: Pituitary carcinoma in situ. Endocr Pract 19:e69-73, 2013

8. Raverot $G$, Sturm N, de Fraipont F, Muller M, Salenave S, Caron P, Chabre O, Chanson P, Cortet-Rudelli C, Assaker R, Dufour $\mathrm{H}$, Gaillard S, Francois P, Jouanneau E, Passagia JG, Bernier M, Cornelius A, Figarella-Branger D, Trouillas J, Borson-Chazot $\mathrm{F}$, Brue T: Temozolomide treatment in aggressive pituitary tumors and pituitary carcinomas: A French multicenter experience. J Clin Endocrinol Metab 95:4592-4599, 2010

9. Zemmoura I, Wierinckx A, Vasiljevic A, Jan M, Trouillas J, Francois $P$ : Aggressive and malignant prolactin pituitary tumors: Pathological diagnosis and patient management. Pituitary 16(4):515-522, 2013 